\title{
Effects of different media concentartions on callogensis in sugar cane (Saccharum officinarum L.)
}

\author{
Waleed Ahmad Khattak ${ }^{1}$, Mazhar UI-Islam ${ }^{2}$ and Ihsan Ullah ${ }^{1,3 *}$ \\ ${ }^{1}$ Sarhad University of Science and Information Tehnology, Peshawar, Pakistan. \\ ${ }^{2}$ Department of Chemical Engineering, Daegu, South Korea. \\ ${ }^{3}$ Institute of Biotechnology And Genetic Engineering KPK Agricultural University Peshawar, Pakistan.
}

Received 3 December, 2012; Accepted 8 August, 2013

\begin{abstract}
Sugarcane (Saccharum officinarum L) var. 668 was propagated through tissue culture technique: callogenesis at MS media supplemented with different concentrations of growth regulators. Explants were disinfected with $70 \%$ ethanol which was sprayed directly on outer most sheathe which covered the tender stem to be used as source of explants. After $\mathbf{1 5}$ days, those explants which survived turned into green leaves and were used for the aforementioned study. Different concentrations of growth regulators were applied. For callogensis response from the cultivated explant, combination of Murashige and Skoog (MS) + 2,4-dichlorophenoxy acetic acid (2,4.D) + benzylaminopurine (BAP) with different concentration was applied and were found best for the establishment of callus from shoot culture.
\end{abstract}

Key words: Saccharum officinarum L, callogenesis, growth regulators, explants, shoot culture.

\section{INTRODUCTION}

Plant tissue culture techniques have become a powerful tool for studying and solving basic and applied problems in plant biotechnology. During the last 30 years, micro propagation and other in vitro techniques became more widely used in commercial horticulture and agriculture for the mass propagation of crop plants (Lal and Singh, 1994). Sugarcane (Saccharum officinarum L.) is an important agricultural cash crop of Pakistan and is the major source of sugar. Enhancement of sugarcane productivity mainly depends on genetic variability available and pyramiding of the potential genes (Lee, 1987). Genetic improvement in sugarcane via conventional breeding is greatly limited due to the fact that sugarcane plant scarcely flower and produce seeds under our climatic conditions (Lorenzo et al., 2001). Breeding work in sugarcane is mainly dependent on imported fuzz of inferior quality and, therefore, the available genetic base for selection of desirable genotypes is very narrow (Krisnamurthi and Tlaskal, 1974; Azeem et al., 2010). In spite of concerted efforts, a breakthrough in sugarcane yield and sucrose content could not be achieved. Likewise existing procedures for sugarcane multiplication has long been a time consuming problem in sugarcane breeding program. Micro propagation is currently the only realistic means of achieving rapid, large-scale production of disease-free quality planting material as seed canes of newly developed varieties in order to speed up the breeding and commercialization process in sugarcane. As a result of which, plant regeneration through tissue culture technique would be a viable alternative for improving the quality and productivity in sugarcane. There are reports

*Corresponding author. Email: insanullahcharm@hotmail.com.

Abbreviations: MS, Murashige and Skoog; 2,4-D, 2, 4- dichlorophenoxy acetic acid; BAP, benzylaminopurine; NAA, naphthalene acetic acid. 
on tissue culture of sugarcane from different countries but the first attempts to regenerate plants through in vitro technique were made on sugarcane by Naz (2003). Standardization of protocols for in vitro multiplication of sugarcane through callus culture, axillary bud and shoot tip culture have been reported by many authors (Devi and Srinivasan, 2006). However, reports are few on young meristem callus culture in sugarcane cultivar, Nayana of Orissa. The present communication demonstrates an effective high frequency regeneration method which allows for expedient multiplication of micro plants that are easily established ex vitro through callus culture of young meristem as an explant.

\section{MATERIALS AND METHODS}

This research project was carried out in the Nuclear Institute for Food and agriculture Turnab Peshawar (NIFA). All the facilities and equipments were provided by NIFA and Sarhad University of Science and Information Technology Peshawar (SUIT).

\section{Maintenance of aseptic environment}

\section{Sterilization of glassware}

Glassware (Petri plates, vials, culture tube, flasks, pipettes among others) and metallic instruments were sterilized in a hot air oven at $160-180^{\circ} \mathrm{C}$ for $2 \mathrm{~h}$.

\section{Sterilization of instruments}

The metallic instruments (forceps, scalpels, needles, spatulas, among others) were first sterilized in hot air oven at $160-180^{\circ} \mathrm{C}$ covered by aluminum sheet and then flame sterilized, that is, dipping them in $70 \%$ ethanol followed by flaming and cooling in luminary flow.

\section{Sterilization of nutrient media}

Culture media were properly dispensed in glass container, plugged with cotton, sealed with plastic closures and sterilized by autoclaving. Minimum time required for autoclaving the nutrient media are:

\section{Selection of explants}

Explant was conducted on sugar cane (S. officinarum L.) collected from field grown plants.

\section{Growth medium}

MS medium (Murashiage and Skoog, 1962) supplemented with different concentrations of auxin and cytokinins along with $4 \%$ sucrose were used.

\section{Callogenesis}

Explants were obtained from shoots of sugarcane plant. The shoot was surface sterilized in $75 \%$ ethanol for 1 min, disinfected in $2 \%$ sodium hypochlorite solution for 2 min, and washed 7 times with sterile water. After removal of several outer layers of leaves, the innermost segments, starting at the base of the leaves and up to 8 $\mathrm{cm}$ towards the tip were cut off with a sharp sterilized scalpel. The sequential leaf segments, with a cut surface in contact with the culture medium, were placed in each Petri dish $(100 \times 15 \mathrm{~mm})$ containing approximately $30 \mathrm{ml}$ of the medium. All 48 explants were grown on the MS medium supplemented with different concentrations and combination of auxin and cytokine: $M S+2,4-$ dichlorophenoxy acetic acid (2, 4-D) (2 mg/L); MS + 2, 4-D (3 $\mathrm{mg} / \mathrm{L}) ; \mathrm{MS}+2$, 4-D $2 \mathrm{mg} / \mathrm{L}+$ benzylaminopurine (BAP) $(1 \mathrm{mg} / \mathrm{L})$ and $\mathrm{MS}+2,4-\mathrm{D} 3 \mathrm{mg} / \mathrm{L}+\mathrm{BAP} 1 \mathrm{mg} / \mathrm{L}$. All cultures were incubated in the dark at $27^{\circ} \mathrm{C} \sim$ for callus induction and growth.

\section{RESULTS AND DISCUSSION}

Callus induction was observed within two weeks, after inoculation of the explants on MS medium (Figure 1) supplemented with 2, 4-D and BAP. Although in all concentrations of 2, 4-D the callus induction was triggered, but maximum callus growth was observed at the concentration of $3 \mathrm{mg} / \mathrm{l}$ of 2, 4-D (70\%). However, more profuse callus induction was observed at $3 \mathrm{mg} / \mathrm{l}$ of 2, 4-D + $1 \mathrm{mg} / \mathrm{l}$ of BAP with full potential of callus regeneration from the explants of the cultivated varieties, Nayana. On this media composition, the explants produced creamy white callus. The percentage of callus induction was $77 \%$ (Table 1). Such type of calli has also been reported by Khan et al. (1998), Nadar et al. (1978) and Begum et al. (1995) who found that $3.5 \mathrm{mg} / \mathrm{l}$ of 2, 4-D produced highest percentage of callus induction from leaf base explant in Bangladesh Nagabari variety of sugarcane. Islam et al. (1982) and Azeem et al. (2010) also reported that $0.5-5.0 \mathrm{mg} / \mathrm{l}$ of 2,4-D showed callus induction from leaf tissue on MS medium. The concentrations of naphthalene acetic acid (NAA) at 2.0 and $3.0 \mathrm{mg} / \mathrm{l}$ produced small amount (20-30\%) of callus with grayish globular and hardy in nature.

The hormone mediated callus induction and subsequent growth is dependent on certain factors, that is, appropriate concentration of sucrose and iron source among others, which may trigger the complete chain of events that influence the ability of cultured cells to grow in an organized fashion. Plant tissues, therefore, must have receptors for hormones for example GID1 and DELLA. These hormones interact with these receptors that reside either on cell membrane or within the cytoplasm. Affinity and concentration of receptors on the surface of the target tissues determine the type of response. Previously specific binding site for both auxin and cytokinin have been identified. A class of proteins called expansins mediates the proton ability to cause cell wall loosening; these expansins break the hydrogen bonds between the polysaccharide components of the wall. Proton $(\mathrm{H}+)$ pumping and lowering of cytosolic $\mathrm{pH}$ result in an elevation of intracellular calcium level. Both cytosolic $\mathrm{pH}$ and calcium ions act as second messengers in early auxin action. Calcium ions, either themselves and or along with calcium binding proteins, for example, 


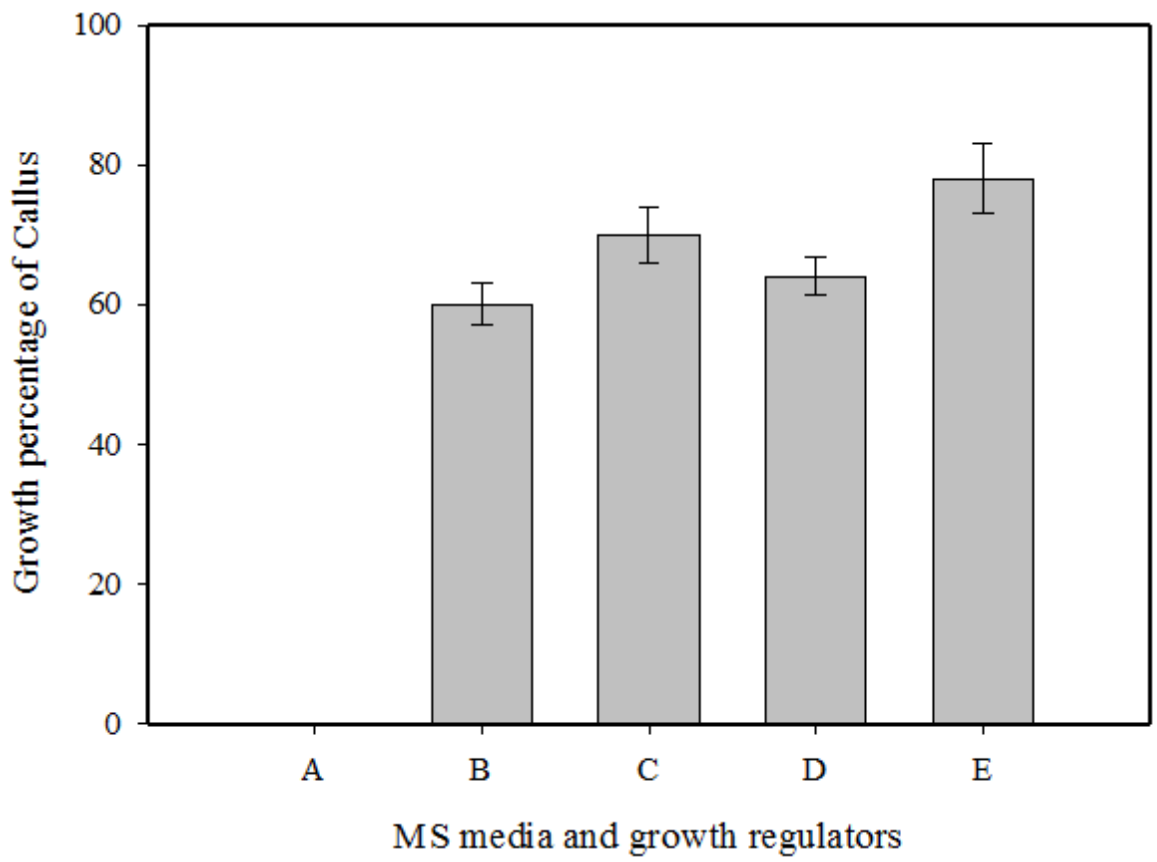

Figure 1. Healthy young meristems were collected by removing the leaf sheath from field grown plants of sugarcane (Saccharum officinarum L.). The explants was grown on the MS medium supplemented with different concentrations of auxin and cytokine on the callus formation in sugarcane. A, MS; B, MS + 2, 4-D (2 mg/L); C, $\mathrm{MS}+2$, 4-D (3 mg/L); D, MS + 2, 4-D (2mg/L)+ BAP (1 mg/L); E, MS + 2, 4-D (3 $\mathrm{mg} / \mathrm{L})+\operatorname{BAP}(1 \mathrm{mg} / \mathrm{L})$.

Table 1. Effect of Auxin and Cytokine's on the callus morphology, viability, totipotency and callogenesis.

\begin{tabular}{|c|c|c|c|c|}
\hline Media concentration & $\begin{array}{l}\text { Total number of } \\
\text { explants culture }\end{array}$ & $\begin{array}{l}\text { Callus } \\
\text { induction }\end{array}$ & $\begin{array}{c}\text { Percentage (\%) Callus } \\
\text { formation }\end{array}$ & Remark \\
\hline $\mathrm{MS}+2,4-\mathrm{D}(2 \mathrm{mg} / \mathrm{L})$ & 48 & 29 & 60.4 & Yellowish Callus \\
\hline $\mathrm{MS}+2,4-\mathrm{D}(3 \mathrm{mg} / \mathrm{L})$ & 48 & 34 & 70.8 & Yellowish to Brown Callus \\
\hline $\begin{array}{l}\mathrm{MS}+2,4-\mathrm{D}(2 \mathrm{mg} / \mathrm{L})+\mathrm{BAP} \\
(1 \mathrm{mg} / \mathrm{L})\end{array}$ & 48 & 31 & 64.6 & Light White Callus \\
\hline $\begin{array}{l}\mathrm{MS}+2,4-\mathrm{D}(3 \mathrm{mg} / \mathrm{L})+\mathrm{BAP} \\
(1 \mathrm{mg} / \mathrm{L})\end{array}$ & 48 & 37 & 77.1 & $\begin{array}{l}\text { Light White Callus with } \\
\text { Good Growth }\end{array}$ \\
\hline MS (Basic) & 48 & - & - & - \\
\hline
\end{tabular}

calmodulin activate the protein kinase cascade which in turn activates other proteins, including the transcription factors. These factors presumably interact with the auxinresponse elements and regulate the expression of auxininducible or auxin-responsive genes and exert its effect on cell cycle and stimulate cell division.

\section{Conclusion}

It is concluded from the present investigation that maximum growth percentages $(77.1 \%)$ was obtained at 3 $\mathrm{mg} / \mathrm{l}$ of $2,4-\mathrm{D}+1 \mathrm{mg} / \mathrm{l}$ of BPA while exclusive 2 , 4-D at the concentration of $3 \mathrm{mg} / \mathrm{l}$ maximum gave (70.1\%) callus growth. So $3 \mathrm{mg} / \mathrm{l}$ of 2, 4-D $+1 \mathrm{mg} / \mathrm{l}$ of BPA is suggested as ideal for maximum callus growth.

\section{ACKNOWLEDGMENTS}

Authors express their genuine thanks to the Department of Biotechnology, Sarhad University of Science and Information Technology, Pakistan for providing financial support and Biotechnology Lab. at Nuclear Institute for Food and Agriculture (NIFA), Tarnab Peshawar, Pakistan for providing research facilities. 


\section{REFERENCES}

Azeem SA, Ullah I, Ali M, Khan A, Bakht J (2010). Effects of different sterilents on seeds and Callusing frequency as effected by hormones in Nicotiana tabacum L. Biofrontiers 1: 62-67

Devi CV, Srinivasan BK (2006). Studies on various atmospheric Microorganisms affecting the plant tissue culture explants. Am. J. Plant Physiol. 1: 205-209.

Islam AS, Begum HA, Haque MM (1982). Regeneration of Saccharum officinarum for disease resistant Varieties. Proc. Int. Cong. Plant Tissue Cell Cult. 5: 709-710.

Khan IA, Khatri A, Ahmed M, Siddiqui SH, Nizamani GS, Khanzada MH, Dahar NA, Khan R (1998). In vitro mutagenesis in sugarcane. Pak. J. Bot. 30: 253-261.

Krisnamurthi M, Tlaskal J (1974). Fiji disease resistant. Saccharum officinarum L. var. Pindar subclone from tissue culture. Proc. Intl. Soc. Sugarcane Technol. 15:130-137.
Lal N, Singh HN (1994). Rapid clonal multiplication of sugarcane through tissue culture: Plant Tissue Cult. 4: 1-7.

Lee TSG (1987). Micropropagation of sugarcane (Saccharum spp.) Plant Cell Tissue Org. Cult. 10: 47-55.

Lorenzo JC, Ojeda E, Espinosa A, Borroto, C (2001). Field performance of temporary immersion bioreactor derived sugarcane plant. Biol. Plant 37: 803-806.

Nadar HM, Soepraptop S, Heniz DJ (1978). Fine structure of sugar cane (Saccharum Spp.) callus and the role of auxin in emberyogenesis . Crop Sci.18:210-216.

Naz S (2003). Micropropagation of promising varieties of sugarcane and their acclimatization response. Activities on Sugar Crops in Pakistan. Proc. Fourth Workshop Res. and Dev. 12:1-9. 